\title{
КОГНІТИВНИЙ КОМПОНЕНТ ПРОФЕСІЙНО ОРІЕНТОВАНОЇ КОМУНІКАТИВНОЇ КОМПЕТЕНЦЇ̈ МАЙБУТНІХ ФАХІВЦІВ МОРСЬКОЇ ГАЛУЗІ
}

\author{
Мороз О. Л. \\ кандидат філологічних наук, дочент, \\ доиент кафедри англійської мови в судноводінні \\ Херсонська державна морська академія \\ пр. Ушакова, 20, Херсон, Україна \\ orcid.org/0000-0002-1483-9136 \\ alyona_moroz@ukr.net \\ Бондаренко В. В. \\ асистент кафедри англійської мови в судноводінні \\ Херсонська державна морська академія \\ пр. Уиакова, 20, Херсон, Украӥна \\ orcid.org/0000-0002-1483-9136 \\ valeo2valeo@gmail.com
}

\author{
Ключові слова: \\ професійна підготовка, \\ професійно орієнтоване \\ спілкування, активне \\ навчання, контекстне \\ навчання, критичне мислення, \\ морська англійська мова.
}

У статті розкрито сутність когнітивного компонента структури професійно орієнтованої комунікативної компетенції майбутніх фахівців морської галузі та описано особливості його формування та розвитку під час занять 3 англійської мови. Стверджується, що аналіз структури комунікативної компетенціїтаїї складниківсприяє розуміннюії сутності, аотже, уможливлює пошук більш ефективних шляхів iї формування та удосконалення. Когнітивний компонент структури професійно-орієнтованої комунікативної компетенції визнається разом із лінгвістичним та стратегічним одним 3 ядерних компонентів всієї структури. Тобто розглядаємо його як такий, без якого здійснення професійної діяльності не можливе взагалі, оскільки він включений до переліку мінімальних необхідних для виконання посадових обов'язків компетенцій фахівця морської галузі. Цей компонент включає в себе необхідні професійні знання, уміння та навички, а отже, вважаємо, що від сформованості цього компонента ПОКК залежить успішність виконання правильної послідовності етапів усіх циклів професійної діяльності. У статті стверджується, що формування когнітивного компонента структури комунікативної компетенції має відбуватися на засадах реалізації принципу раннього професійного спрямування навчання іншомовного спілкування та пропонується низка заходів, спрямованих на забезпечення реалізації цього принципу. Така рання професійна спрямованість змісту навчання іноземної мови значно підвищує інтерес студентів до предмета, забезпечує особливу мотивацію до навчання, розширює словниковий запас, сприяє інтеграції фахових знань у сферу іншомовного спілкування. Зазначено, що, хоча процес формування означеного компонента структури комунікативної компетенції має формуватися безперервно протягом усього періоду навчання курсантів у вищому морському навчальному закладі, на кожному етапі навчання $€$ певні особливості, які необхідно враховувати у процесі планування навчальної діяльності. Доведено, що важливим показником сформованості когнітивного компонента є здатність курсантів до критичного мислення, а отже, реалізація принципу контекстного навчання має відбуватися в поєднанні із залученням стратегій активного навчання. 


\title{
COGNITIVE COMPONENT OF PROFESSIONALLY-ORIENTED COMMUNICATIVE COMPETENCY OF FUTURE SEAFARERS
}

\author{
Moroz O. L. \\ Candidate of Philological Sciences, \\ Associate Professor at the English Language Department for Deck Officers \\ Kherson State Maritime Academy \\ Ushakova avenue, 20, Kherson, Ukraine \\ orcid.org/0000-0002-1483-9136 \\ alyona_moroz@ukr.net \\ Bondarenko V. V. \\ Assistant at the English Language Department for Deck Officers \\ Kherson State Maritime Academy \\ Ushakova avenue, 20, Kherson, Ukraine \\ orcid.org/0000-0002-1483-9136 \\ valeo2valeo@gmail.com
}

Key words:

professional training,

professionally-oriented

communication, active learning,

content and language integrated

learning, critical thinking,

Maritime English.
The article reveals the cognitive component contents of the professionallyoriented communicative competency structure of future seafarers. It also suggests the description of the peculiarities of its formation and development during the English language lessons. It is proposed that communicative competency structure analysis with the component description promotes the understanding of its essence and, in such a way, enables the search of more effective means of its formation and refinement. The cognitive component of the professionally-oriented communicative competency structure is acknowledged in the paper, together with the linguistic and the strategic ones, as one of the core structural components. It means, that we consider it as the one without which it is completely impossible to carry out the professional activity as it is included into the list of minimum required competencies of future seafarers. The component includes required professional knowledge, skills and abilities (like ship stability features, ship arrangement, rules of the road, etc.). That's why we believe that the extent to which the component is developed influences the successful performance of all stages of the professional activity. In the article it is also claimed that the formation of the cognitive component of professionally-oriented communicative competency structure should be carried out on the basis of the principle of early professional orientation of the English language teaching. It is also suggested the list of possible measures for the principle realization. Such early professional orientation of the foreign language teaching considerably motivates the students and promotes their interest to the discipline, helps to enlarge students' professional vocabulary and provides for the integration of professional knowledge into language competency. It is stated that, though the process of the cognitive component formation should be carried out continuously through all educational period in the higher maritime educational institution, each stage of the educational process is characterized by specific peculiar features which must be taken into consideration when planning the lessons and teaching activities. It has been proved that students' ability to critical thinking is one of the criterion showing the cognitive component level, so we suggest that the content integrated learning should be carried out together with the active learning strategies involved. 
Останнім часом проблеми професійної підготовки фахівців різних галузей та вимоги до їх компетенцій привертають увагу науковців, активно обговорюються, вивчаються на різних рівнях. Особливо це стало актуальним у зв'язку з приєднанням до Болонського процесу, адже перед вищою школою постало надважливе завдання підготувати компетентного фахівця. В епоху розвинених комунікацій успіх людини, в тому числі й у професійній сфері, часто залежить від глибини засвоєння мови, гнучкості у використанні вербальних засобів, культури мовлення тощо [1, с. 76].

На думку провідних вітчизняних науковців (В. Андрущенко, П. Бех, І. Зязюн, В. Кремень, Г. Онкович, В. Редько та ін.), якість вищої освіти великою мірою залежить від рівня володіння випускниками університетів іноземними мовами. Саме тому дослідники намагаються вирішити нагальні методологічні питання підвищення ефективності професійно орієнтованої іншомовної підготовки майбутніх медичних працівників (Т. Бажан, А. Гулак, Н. Кучумова, Л. Манюк, С. Поплавська), інженерів різних галузей виробництва (3. Корнєва, О. Ларіонова, О. Можаровська), менеджерів із туризму та маркетологів (Н. Івасів, І. Кодлюк, А. Онуфрів, В. Сідоров), офіцерів та військовослужбовців (С. Білявець, I. Ковальчук, О. Павленко), журналістів (С. Коновальчук) тощо.

Морська англійська мова, визнана Міжнародною морською організацією робочою мовою на суднах торгівельного флоту, є надважливим компонентом професійної компетентності фахівців морської галузі. Згідно з нормативними документами, які регламентують вимоги до мінімальних стандартів підготовки моряків, кожен морський офіцер має володіти на належному рівні англійською мовою для ефективного спілкування 3 членами екіпажу [2], а отже, формування професійно-орієнтованої комунікативної компетенції (ПОКК) та готовності курсантів вищих морських навчальних закладів до професійно орієнтованого іншомовного спілкування $є$ важливим складником їхньої професійної підготовки.

Погоджуючись із твердженням, що «іншомовна мовленнєва комунікативна компетенція $\epsilon$ багатокомпонентним утворенням, яке включає кілька видів компетенцій» [3, с. 62], вважаємо, що розумінню сутності поняття КК та шляхів іiі формування й удосконалення, особливо для певної цільової групи, сприяє аналіз іiї структури. Грунтовний аналіз наукового доробку свідчить про те, що вчені не дійшли єдності щодо структури КК. Однак слідом за О. Павленко вважаємо, цей факт зумовлюється тим, що науковці, по-перше, спираються в дослідженнях на різні підходи (лінгводидактичний, соціолінгвістичний, прагматичний, функціональний тощо), а по-друге, описують структуру КК для різних цільових груп і предметних сфер [1, с. 64]. Так, Д. Ізаренков фокусується на базисних складових частинах КК і iii формуванні у студентів-нефілологів [4]. О. Павленко здійснено аспектний аналіз компонентів комунікативної компетенції митників [1], у дослідженні I. Секрет запропоновано уточнення компонентного складу іншомовної професійної компетентності студентів вищих технічних навчальних закладів [5] тощо.

Оскільки у вищому навчальному закладі відбувається вже профільна (професійно орієнтована) іншомовна підготовка майбутніх фахівців, то і структура ПОКК може різнитися залежно від спеціальності, а отже, перед науковцями постає завдання з'ясувати особливості структури ПОКК для тієї чи іншої професійної діяльності майбутніх фахівців. Проведений грунтовний аналіз наукового доробку та власний досвід викладання морської англійської мови дав змогу вибудувати структуру ПОКК майбутніх фахівців морської галузі, у складі якої доцільно, на нашу думку, виділяти ядерні компоненти - такі, без яких здійснення професійної діяльності не можливе взагалі і які розглядаємо як мінімальний необхідний для виконання посадових обов'язків перелік компетенцій фахівця морської галузі, та периферійні компоненти - такі, що є, безперечно, важливими як для здійснення професійної діяльності, оскільки можуть iï покращити, так і для соціальної активності на борту судна, адже моряки співіснують один 3 одним у власному мікросоціумі протягом багатьох місяців. До ядерних компонентів ПОКК у нашому дослідженні зараховуємо лінгвістичний, когнітивний та стратегічний. Зважаючи на обмеження рамками статті, зосередимось на детальному описі когнітивного компонента ПОКК. Отже, мета статті полягає в з'ясуванні сутності когнітивного компонентв ПОКК майбутніх фахівців морського флоту та особливостей його формування та розвитку під час занять 3 англійської мови.

Під когнітивним компонентом розуміємо сформований «тезаурус особистості», в якому відбивається система знань про світ, іiї здатність збагнути «картину світу» [6, с. 238], зокрема професійну. Тобто когнітивний компонент ПОКК включає знання, навички і здібності, які необхідні для виконання будь-якої діяльності, особливо специфічної (якою, на нашу думку, є професійна діяльність), оскільки саме наявність таких знань уможливлює виконання завдань, знаходження рішень для певних професійних задач та проблемних професійних ситуацій. Цей компонент комунікативної структури охоплює не лише «офіційні» знання [1, с. 72], отримані під час навчання у ВН3 
та/або з мануалів, інструкцій з експлуатації тощо, а й знання, що грунтуються на власному досвіді.

Від сформованості цього компонента ПОКК залежить успішність виконання правильної послідовності етапів усіх циклів професійної діяльності: управлінського (планування діяльності, надання інструкцій, контроль), операційного (аналіз та оцінка поточної професійної ситуації, антиципація можливих варіантів розвитку подій, вироблення можливих варіантів подальших дій та, зрештою, прийняття остаточного рішення) та допоміжного (сприйняття наданих інструкцій, їх адекватна інтерпретація та розуміння, правильне виконання тощо).

Процес професійної комунікації фахівців морської галузі охоплює різні сторони діяльності, які потребують певного рівня знань із різних сфер: про будову судна, про роботу суднових механізмів, про властивості вантажу, що перевозиться, про вплив навколишніх факторів на пересування та остійність судна та багато іншого. Практична реалізація цього компонента ПОКК, згідно 3 твердженням Д. Ізаренкова, відбувається у змістовому, денотативному плані висловлювань, в якому відображуються фрагменти знання людини про цей світ $[4$, с. 56]. Таке тлумачення дає змогу методично правильно дійти до рішення про відбір навчальних текстів, тематики створюваних мовленнєвих ситуацій, за допомогою яких здійснюватиметься процес навчання морської англійської мови. У них має знайти відображення інформація про предметні (професійні) сфери, володіючи якою, курсанти зможуть розпізнавати та породжувати власні висловлювання. У зв'язку із цим характерною особливістю викладання морської англійської мови так само, як і будь-якої іншої іноземної мови для спеціальних цілей, визнаємо планування навчального процесу згідно зі специфічними професійними потребами суб'єктів навчання 3 обов'язковим змістовним співвідношенням іноземної мови та інших предметів циклу професійної підготовки.

Слідом за Р. Гришковою вважаємо, що формування когнітивного компоненту ПОКК майбутніх фахівців морської галузі має відбуватися на засадах реалізації такого важливого принципу навчання іноземної мови студентів нефілологічних спеціальностей, як принцип раннього професійного спрямування навчання іншомовного спілкування [3, с. 94]. Мається на увазі, що з першого курсу на заняттях із морської англійської мови студентів треба поступово вводити у світ їхніх професійних інтересів, відбираючи для вивчення теми професійно спрямованого змісту за вибраним студентами фахом. Як свідчить власна багаторічна викладацька практика, рання професійна спрямованість змісту навчання іноземної мови значно підвищує інтерес студентів до предмета, забезпечує особливу мотивацію до навчання, розширює словниковий запас, сприяє інтеграції фахових знань у сферу іншомовного спілкування. Саме тому у процесі роботи над удосконаленням змісту робочих навчальних програм було прийнято низку важливих рішень:

- змінити назву дисципліни «Англійська мова за професійним спрямуванням» на «Морська англійська мова» 3 метою точного відображення змісту навчальної дисципліни (3 2019-2020 н.р.);

- відмовитися від вивчення загальноакадемічних тем (типу «Shopping», «Where I live», «Everyday life», «Travelling» тощо) та вже 3 першого семестру першого курсу навчання розпочинати курс із вивчення професійно значущих тем («Maritime Education», «Career Awareness», «Ship Arrangement», «Bulk cargo carriers» та ін.) (3 2020-2021 н.p);

- запровадити вивчення загальної морської мови (General Maritime English) на всіх факультетах та напрямах підготовки (судноводіння, експлуатація суднових енергетичних установок, експлуатація суднового електрообладнання і засобів автоматики) протягом перших трьох семестрів навчання, оскільки на цьому етапі здійснюється підготовка молодшого рядового складу, який має виконувати обов'язки на допоміжному рівні відповідальності [2, с. 124-126], а отже, володіти загальними комунікативним вміннями на позначення частин судна, типів суден та суднового обладнання, типів вантажів та їхніх характеристик тощо;

- переходити до вивчення спеціалізованої англійської мови (Specialized Maritime English) згідно 3 вибраною спеціальністю з четвертого семестру, оскільки після закінчення другого курсу курсанти розпочинають плавальні практики у складі відповідних відділень суднового екіпажу та готуються до виконання посадових обов'язків на операційному рівні відповідальності, а значить, мають володіти грунтовними професійними знаннями зі своєї галузі знань.

Тобто із самого початку навчання у вищому морському навчальному закладі викладання дисципліни «Морська англійська мова», на наше глибоке переконання, має відбуватися на основі підходу предметно-мовного інтегрованого навчання (CLIL - Content and Language Integrated Learning), в рамках якого вивчення англійської мови відбувається під час вивчення тем та матеріалів зі спеціальних фахових дисциплін. Інтеграція професійних знань до процесу навчання іноземних мов задля професійного спілкування сприяє вияву зрілих когнітивних здібностей. Ця інтеграція $€$ важливою для вдосконалення комунікативних здібностей, оскільки актуалізація знань із предмета 
створює внутрішню потребу висловитися щодо ситуацій професійної діяльності фахівця.

Процес формування когнітивного компонента ПОКК майбутніх фахівців морської галузі має реалізовуватися безперервно протягом усього періоду навчання у ВНЗ. Однак кожен етап навчання, безперечно, має особливості. Так, щодо першого етапу навчання, коли курсанти ще не мають стійких грунтовних знань із майбутньої професій, йдеться про необхідність створення навчальних ситуацій спілкування, в яких вони матимуть змогу продукувати висловлювання (в усній та/або письмовій формі) за вивченою тематикою та знайомими комунікативними ситуаціями, які вводяться та практикуються протягом одного чи навіть кількох занять. На другому етапі професійної підготовки курсанти вже володіють певним багажем як теоретичних, так і практичних знань, оскільки вже побували на виробничій практиці та мають реальний плавальний досвід. На цьому етапі навчання варто пропонувати не відтворення вивчених ситуацій, а продукування рішень до окреслених професійних проблемних ситуацій, тобто забезпечити реалізацію квазіпрофесійної діяльності, яка моделює реальні виробничі умови 3 конкретними завданнями та задачами й уможливлює їх вирішення засобами англійської мови. Під час навчання в магістратурі, на останньому етапі професійної підготовки в рамках формальної освіти, курсантам необхідно давати змогу самостійно працювати над проектними та дослідницькими завданнями професійного характеру, в яких вони зможуть реалізувати та вдосконалювати інші важливі для майбутніх моряків особисті якості.

Принцип контекстного професійного навчання не лише дасть змогу поглибити фахові знання, а й уможливить розвиток критичного мислення, аналітичні здібності, що є так само важливо, адже випускники морських ВН3 - це майбутні офіцери, які мають бути здатними до керування екіпажем, швидкого прийняття важливих рішень у критичних ситуаціях тощо. 3 метою розвитку здібностей курсантів до критичного мислення, яке є важливим показником сформованості когнітивного компонента ПОКК майбутніх фахівців морської галузі, реалізація принципу контекстного навчання має відбуватися в поєднанні із залученням стратегій активного навчання (Active Learning Strategies). Ми глибоко переконані, що традиційний підхід до навчання, коли знання передаються учням/студентам у формі лекцій, пояснень, розповідей тощо, вже не $\epsilon$ ефективним, оскільки не може забезпечити таку якість освіти, зокрема професійної, якої вимагає сучасний стан суспільства. Перехід людства до нового способу існування, складнішого та більш непередбачуваного, призводить до змін у типі мислення, вимагаючи, щоб воно стало більш креативним, інноваційним та продуктивним. За твердженням Президента Національної Академії педагогічних наук В. Кременя, «нині ми маємо здійснити перехід до креативної парадигми освіти, переосмисливши, таким чином, діяльність навчальних закладів усіх типів. Зокрема, потрібно використовувати освітні технології, які спонукають учнів до творчого пошуку, пробуджують пізнавальний інтерес, дають змогу бачити результат і перспективу навчання» [7, с. 6]. Так само і для професійної освіти майбутніх фахівців морської галузі вважаємо за необхідне не лише сформувати навички та компетенції, які прописані у мінімальних вимогах до їх підготовки [2], а й забезпечити розвиток здібностей до критичного мислення та підвищувати їх інтелектуальний рівень, що дасть їм змогу адаптуватися та адекватно реагувати на непередбачувані та мінливі ситуації та обставини їхнього складного професійного середовища. Ефективним засобом для досягнення цієї мети і $\epsilon$, на нашу думку, стратегії активного навчання.

Активне навчання включає в себе широкий спектр технологій, які уможливлюють активне залучення курсантів/студентів до процесу навчання як активних учасників за допомогою дискусій, створення проблемних ситуацій, кейс-технологій, дослідницького навчання та інших методів. Головний фокус уваги сконцентровано на тому, як саме курсанти вчаться, а не тільки на тому, що вони вивчають. Такі стратегії допомагають розвивати мислення, застосовувати набуті знання.

Отже, підсумовуючи все вищезазначене, переконані, що когнітивний компонент $є$ дуже важливим у структурі ПОКК майбутніх фахівців морської галузі. Він уможливлює здатність обирати адекватні лінгвістичні засоби відповідно до комунікативних ситуацій, здійснювати правильну референцію, співвідносити ментальні схеми з явищами реальної дійсності, інтегрувати мовні уміння та навички з уміннями застосовувати професійні знання для вирішення проблемних професійних ситуацій засобами іноземної мови. Подальшою перспективою дослідження $\epsilon$ визначення необхідних периферійних компонентів структури ПОКК майбутніх фахівців морської галузі та з'ясування особливостей їх формування в системі неперервної професійної освіти. 


\section{Література}

1. Павленко О.О. Формування комунікативної компетенції фахівців митної служби в системі непевної професійної освіти : дис. ... Д-ра пед. наук : 13.00.04. Дніпропетровськ, 2010. 560 с.

2. Международная конвенция о подготовке и дипломировании моряков и несении вахты 1978 года с поправками (консолидированный текст) / пер.: В. Стрелков, Т. Кузнецова, С. Лапченков. Санкт-Петербург : ЗАО «ЦНИИМФ», 2010. 805 с.

3. Гришкова Р.О. Педагогічні засади формування іншомовної соціокультурної компетенції студентів нефілологічних спеціальностей у процесі фахової підготовки : дис. ... д-ра пед. наук : 13.00.04. Київ, 2007. 446 с.

4. Изаренков Д.И. Базисные составляющие коммуникативной компетенции и их формирование на продвинутом этапе обучения студентов-нефилологов. Русский язык за рубежом. 1990. № 4. С. 54-60.

5. Секрет I.В. Теоретичні та методичні основи формування іншомовної професійної компетентності студентів вищих технічних навчальних закладів в умовах дистанційної освіти : дис. ... д-ра пед. наук : 13.00.04. Київ, 2012. 552c.

6. Караулов Ю.Н. Русский язык и языковая личность. Москва : Наука, 1987. 262 с.

7. Кремень В.Г. Нові вимоги до якісної освіти. Освіта Украӥни. 2006. № 45/46. С. 6-7.

\section{References}

1. Pavlenko, O.O. (2010). Formuvannia komunikatyvnoi kompetentsii fakhivtsiv mytnoi sluzhby v systemi nepevnoi profesiinoi osvity [Communicative Competency Formation of Future Custom Service Specialists in the Framework of Continuous Professional Education]. Doctor's Thesis. Dnipropetrovsk. 560 p.

2. Strelkov, V., Kuznecova, T. (Translation) (2010). Mezhdunarodnaja konvencija o podgotovke i diplomirovanii morjakov i nesenii vahty 1978 goda s popravkami (konsolidirovannyj tekst) [International Standards on Training, Certification and Watchkeeping 1978 (consolidated edition)]. Sankt-Peterburh: ZAO «TsNYYMF». $805 \mathrm{p}$.

3. Hryshkova, R.O. (2007). Pedahohichni zasady formuvannia inshomovnoi sotsiokulturnoi kompetentsii studentiv nefilolohichnykh spetsialnostei u protsesi fakhovoi pidhotovky [Pedagogical grounds of foreign sociocultural competency formation of non-philological students in the process of professional training]. Doctor's Thesis. Kyiv. 446 p.

4. Izarenkov, D.I. (1990). Bazisnyie sostavlyayuschie kommunikativnoy kompetentsii i ih formirovanie na prodvinutom etape obucheniya studentov-nefilologov [Basic components of communicative competency and their formation at the advanced level of non-philological students education]. Russian Language abroad. Vol. 4. P. 54-60.

5. Sekret I.V. (2012). Teoretychni ta metodychni osnovy formuvannia inshomovnoi profesiinoi kompetentnosti studentiv vyshchykh tekhnichnykh navchalnykh zakladiv $\mathrm{v}$ umovakh dystantsiinoi osvity [Theoretical and methodological basis of foreign language professional competency formation of the higher educational establishments students in terms of distant learning]. Doctor's Thesis. Kyiv. $552 \mathrm{p}$.

6. Karaulov, Yu.N. (1987). Russkij jazyk i jazykovaja lichnost. [Russian Language and the Language Personality]. Moskva: Nauka. 262 p.

7. Kremen, V.H. (2006). Novi vymohy do yakisnoi osvity [New requirements to high quality education]. Education of Ukraine. Vol. 45/46. P. 6-7. 